\title{
Ethnic Relations in Malaysia from the Perspective of Hadiths
}

\author{
Nazri Muslim ${ }^{1}$, Helimy Aris $^{2} \&$ Nik Yusri Musa ${ }^{3}$ \\ ${ }^{1}$ Pusat Citra, Universiti Kebangsaan Malaysia, Malaysia \\ ${ }^{2}$ Faculty of the Studies of Quran and Sunnah, Universiti Sains Islam Malaysia, Malaysia \\ ${ }^{3}$ The Center of Language Studies and Humanity Development, Universiti Malaysia Kelantan, Malaysia \\ Correspondence: Nazri Muslim, Pusat Citra, Universiti Kebangsaan Malaysia, Malaysia. Tel: 60-19-392-4069. \\ E-mail: nazrim@ukm.edu.my
}

Received: November 8, 2019

Accepted: November 18, 2019

Online Published: November 20, 2019

doi:10.5539/ass.v15n12p140

URL: https://doi.org/10.5539/ass.v15n12p140

\begin{abstract}
Ethnic relations have never escaped Islamic scrutiny. This is made clear through the observation on two of its primary sources, namely the Quran and Hadiths. This is very apparent through the observation about two primary sources namely the Quran and Hadiths. According to Islam, ethnic differences are not the aim as to why humans are created on this earth. According to Islam, ethnic differences are not the sole reason why humans are created on this earth. It does not stop someone from following and practising Islam. It is also unreasonable for one to be discriminated against, and from, getting his or her rights. Thus, this article discusses the hadiths that touch on ethnic relations and the analysis of ethnic relations in Malaysia from the perspective of hadiths.
\end{abstract}

Keywords: Hadiths, ethnic, Malaysia, mankind, Islam, relations

\section{Introduction}

Ethnic relations have never escaped the scrutiny and observation of Islam. This is very apparent through the observation about two primary sources namely the Quran and Hadiths. According to Islam, ethnic differences are not the aim as to why humans are created on this earth. It also does not stop one from following and practising Islam. It should not also become an excuse for one to be discriminated from getting his or her supposed rights that should benefit others. In Quranic and Hadiths terms, humans carry several names among which are al-Insan, al-Nas, al-Ins, al-Basyar and Bani Adam. Every name has its own characteristics and uniqueness, both of which can be discerned through the meanings of the words. Bani Adam refers to generations of Adam. It means that despite the propagation of man into various races, nations and ethnic groups, but it is a fact that humans have the same origin or sulbi which is from Adam. The generations of bani Adam indicate that humans need to live their lives collectively and harmoniously, because life itself has to be shared in all this diversity. Life is the reward of Allah to His creatures including bani Adam.

\section{Hadiths Related to Ethnic Relations}

Islam introduces the concept of ukhuwwah based on faith that transcends the borders of language, race and country. Every Muslim has the rights and responsibilities towards his brothers and sisters without accounting for differences in ethnic and skin colour. Here, Rasulullah s.a.w stated:

A Muslim is a brother to another Muslim, he should not be cruel and let his brother be oppressed. For those who fulfill the intention of their brothers and sisters, Allah s.w.t will fulfill theirs. Those who have released a Muslim from a problem in this world, surely Allah s.w.t will him off a problem in the Hereafter. Those who have covered the humiliation of a Muslim, surely Allah s.w.t will cover his in the Hereafter (al-Bukhari, 1422H).

On the basis of ukhuwwah imaniyyah, Rasulullah s.a.w had made allies between Salman r.a who is a Persian with Abu al-Darda' r.a from the Arab clan. Rasulullah s.a.w action tying friends who had no blood relations or social links is identified as al-Ikha'. When elaborating upon verse 33 Chapter al-Nisa', Ibn Abbas r.a stated:

Once, someone had a dispute with another person who did not have nasab relations with him. And they inherited from one another. Then the practice underwent nasakh with the verse 75 surah al-Anfal (Abu Daud, 2009). 
This strong, cross-ethnic ukhuwwah imaniyyah is evident through the practice of the companions who held closely onto Islamic teaching. `Aiz bin `Amr narrated this:

Abu sufyan r.a (an Arab man) passed by in front of Salman (a Persian) r.a, Suhaib (raised in Rome until he was called Suhaib Al-Rumi) r.a and Bilal (a former slave) r.a. So they stated: "The swords of Allah s.w.t have yet to fulfill the task that should come from His enemies". As he listened to this, Abu Bakar reprimanded them by saying: "How could you say that to the leader of the Quraisy? Then he met with Rasulullah s.a.w and told him about it. Then Rasulullah s.a.w said: "Dear Abu Bakar, maybe you have caused your brothers (Salman, Suhaib and Bilal) to become angry. If you really did so, you have indeed made your God furious with you". Listening to this, promptly Abu Bakar r.a went to see three of them and asked: "Dear brothers, did I make you angry? They answered: "No. May Allah s.w.t forgive your sins my brother" (Muslim, 1422H).

At the same time, Islam prioritises humanity towards all mankind, disregarding differences in ethnicity and faiths.

Sahl bin Hunaif r.a and Qais bin Sa'ad r.a were sitting in al-Qadisiyyah when a body of a non muslim was carried in front of them. So both of them got up and explained ot the people that Rasulullah s.a.w used to do the same thing, which is to stand up when the body of a Jewish man passed him by. He was told then, that it was a body of a Jewish. Then he said: "Isn't he also a human? (al-Bukhari, 1442H).

Non muslims who have obtained citizenship or who have entered a Muslim country legally, are called zimmi or mu ahad meaning people whose rights are protected by Allah s.w.t and Rasul s.a.w. They obtain the rights to live as a citizen. This has been explained in many hadiths. One states:

It should be within your knowledge that those who oppress a mu ahad, reduce his rights, burden him with something out of his capability or confiscate his assets or properties without him consenting to it, I will be his enemy in the Doomsday (Abu Daud, 2009).

Islam clearly forbids defending own ethnic group in the sense of helping and defending own ethnic group who have committed sins or done wrong. This is explained by the prophet in his hadith as follows:

It is not from our people who urge towards the path of asabiyah and also not among us people who fight on the path of asabiyah and people who lose their lives on asabiyah. Listening to this, the companions asked: What do you mean by asabiyah, Rasulullah? He answered: You helping your brothers on the path of cruelty (Muhammad Syams al-Haq, 1990).

The same goes with asabiyah that is often misinterpreted when a group cooperates and negotiates on the basis of their own race - this is also asabiyah. Asabiyah is basically understood as a shallow spirit of racism which is nurtured in the age of ignorance, because of the strong feelings and love for their own group. It is characteristically borderless, where they are willing to kill each other and fight with one another as long as they emerge victorious. Here, it is the victory that matters, not the truth. They defended their own people although it had led to injustice and oppression (Azmi, 2003). Asabiah will only become a problem if it is seen as a replacement for Islam and accompanied by misconstrued understanding that clearly conflicts with Islam (al-Qardhawi, 1996). Based on this hadith, the argument stating that the cause for improving one's race is asabiyah has to be rejected.

Progressing one's own race also striving to become a civilized race mentally and physically, the thinking, materialism, spiritualism and physicality that do not deny and negate the basic rights of other races are also the nature of humanity that wishes to see their race progress and compete, also having good fighting spirit and strong soul in life without neglecting the spiritual aspect and good noble values as their life principles. The previous Prophets and Apostles were created and sent to their own people, except for Muhammad s.a.w. who was sent to the people in general, without accounting for race and generation. This proves that the main focus of the anbiya is to make their people civilized, especially mentally and spiritually.

Rasulullah s.a.w further stated:

And the previous apostles were sent to their people and I was sent to the entire humankind.

Islam does not allow asabiyah thinking that only focuses on their own race, defending and succumbing to any of the actions or doing that comes from their own people, although it clearly conflicts with the truth and there is definite cruelty and oppression from the action. Thus, this is the assertion made by rasulullah s.a.w. when he was asked about the meaning of asabiyah,

It means: Asabiyah is you helping or supporting your own people against cruelty. 
In the Malaysian context, the effort made for the sake of the Malays cannot be regarded as asabiyah. It is because it is done in the spirit of solidarity where the effort to develop the Malays is done without taking the rights of the non-Malays and because of the fact that Malays have lagged far behind other races. Rasulullah s.a.w had also emphasized this in the last sermon (Haji Wida) whereby:

To man, remember that your god is one and your father is one, there is no advantage for the Arab people over the Ajam people, and the Ajam is no superior to Arab and there is superiority of the black people on the red people except if the man has faith and piety (Ahmad Ibn Hamba, 1422H).

The prophet also reminded us:

Those who oppress Dhimmi or make a peace treaty or burden them with something they are not capable of, then I will be the one facing him (Muhammad Syams al-Haq, 1990).

\section{The Analysis of Ethnic Relations in Malaysia Based on Hadith}

Osman Bakar (2008) explains that ethnic relations in Malaysia leans on the introduction of the religion by equating Malay with Islam and equating ethnic interests and religious interests. However, in the future, there will be a change in the trend of the identity of the Malaysian Muslims specifically from Malay ethnicity to various others. For Tariq Ramadan (2004) who looks into ethnic relations in Europe, it is more towards the introduction to religious identity rather than ethnic identity as they constitute a minority in the country where the majority of the residents are non-Muslims. However, earlier on, where Muslim immigrants travelled to Europe, they were still in the dark, whether to call themselves Muslims or Pakistanis, Turkish or Muslim Arabs. This identification of Islamic identity is agreed by Muhammad Mumtaz Ali (1996) as he divided the Muslim community into three groups. The first group is committed to the teaching and identity of Islam. The second group is interested in the Western lifestyle but they do not fully assimilate themselves and the third one, they fully assimilate Western lifestyle in terms of the idea and culture. The first and the third groups make up a minority and the second group is the majority in the West.

Ismail Ibrahim (2005) explains that ethnic relations must lean on the theories of comprehensive Islamic teaching where al-Quran elaborates on the origin of mankind from various ethnic groups. This is in order for humans to live together, communicate and be nice to each other and also to help each other and live in peace, build knowledge and economic and technological strength collectively and collaboratively in all aspects of life. The freedom of religion in Islam is based on one's conviction in choosing his or her religion and the Apostle explains that those in the category of Dhimmi cannot be hurt and fought. Anyone who fights them will be like fighting the Prophets. Such an understanding needs to be understood as it can help people to act upon their evil intention. The concepts of power sharing, the freedom of religion, the protection of the law on weak people is the basis that is blessed in Islam. The conflicts that happened such as the event on 13 May 1969 and the incident in Kampung Medan were not solely due to religion but more influenced by racial sentiment.

Based on the above hadiths, Muhammad Abu Zahrah (1987) reflects that the relationships among the people in the society arranged by the Muslim between the Muslims and the non-Muslims are upheld based on kindness, nobility, fairness, courtesy, negotiations, collective interests, generosity and prevention of negative elements that can be detrimental to the society. These values enable the unity among people of various ethnicity without accounting for skin colour and positions in the society. Human respect is made possible by respecting the heart of the person, without caring for his religion or ethnicity. Thus, he concludes that the relationships of the people in Islam are constructed based on three elements- enabling each and everyone to work hard with the energy that he has, and distributing the work by affordability, giving freedom to everyone by not breaking into other people's rights and helping the weak without accounting for skin colour.

For Yusuf Qardawi (1989), Islam always wants a good relationship between Muslims and non-Muslims based on strong bases of tolerance, fairness, charity and compassion that have never been encountered in the history of mankind before Islam. Thus, the followers of Islam are commanded to make charity and carry out justice to all mankind although the person is a non-Muslim as long as he or she is not against Islam. However, the thing that has become a conflict between people of different religion and ethnicity emerges when they are defeated by lust, fanatism, shallow-mindedness and selfishness.

The same discussion has been raised by a Muslim prominent figure named Said Hawwa (2003) explaining that the differences in race, skin colour, country, family and ancestor are not to differentiate and segregate one another. In actual fact, the differences exist just for the humans to know each other and to love each other. He asserts that humans are all the same in the context of humanity, not distinguished by race, skin colour, family and so on. There is no one citizen who is more special than another and it goes the same way with race. Meanwhile, 
Hasan al-Banna (1403H) explains that human division by race aims to get to know each other and not to cause a dispute or a riot. Thus, Islam fully rejects fanaticism among the race and the segregation that might follow. In turn, the interactions between Muslims and non-Muslims lean on the harmony established in the society and the advantages that humanity brings.

Ethnicity plays the role in consolidating the collaboration in the pluralistic society, at the same time playing the role in strengthening the defensive system of Medina. The togetherness displayed by the people of Medina through the collective agreement on the Constitution of Medina struck as the symbol of success to the management of diversity and pluralism. The acceptance and tolerance of the people of Medina rendered the Medina society a model of management of the diversity and pluralism in the effort to form collaboration, responsibility, fairness and respect among different ethnic groups. The same applies to Malaysia with the communities of various ethnicity and this diversity must be respected by all (Zaleha, Nik Yusri, \& Nazri, 2018).

The discussion of the concept of the protection discrimination does not go on the opposite way from the principle of law equality, to re-marginalise the political, economic and social imbalances amongst the Malaysians. The study outcome also shows that the special position of the Malays does not conflict with the equality principle based on four main contentions, one being that the Malays do gain the access to the special allocations as dictated in the constitution, and it does not go through the process of confiscating non-Malay's properties and assets but instead acquired from the additional assets from the overall economy. Secondly, the implementation of the Malays' special position does not leave an impact on the positions of the economy, education also the politics of the non-Malays, but even in sectors of economy and education, they are in far better position than the Malays. Thirdly, the special position of the Malays is one that has long existed before the Independence and reenacted when the constitution was formulated. Fourth, it is a proposition that has been collectively agreed by the ethnic groups (Nazri, Abdul Latif, \& Mohd Azmir, 2012).

In the context of Malaysia that has various ethnicity, every citizen must respect one another, and acknowledge the rights of every individual and society. Beliefs such as extremism, chauvinism, fanaticism, ethnocentrism, prejudice, stereotype and racism must be cast aside (Wan Suhaimi \& Syed Mohammad Hilmi, 2007, pp. 29-32).

Every Malaysian must strengthen their ethnic relations and always interacts with one another because it is demanded by Islam as explained in Surah al-Hujurat 49: 11 and 13. Other than that, the non-Muslims in Malaysia have benefited their rights as dictated in the Federal Constitution and the rights are consistent with those of the non-Muslims determined by Islam (Muslim \& Umar, 2017). These include the fact that they are free to follow the religion and practise religion peacefully and harmoniously, free to build their own houses of worship, free to eat, drink and dress according to their own cultures, free to find their own sustenance, free to own and manage their own properties, free to elect their own leaders, obtaining the rights of education and health, assured in terms of life security, justice of the laws so on and so forth. For instance, although Chinese-type and Tamil-type primary schools are excluded from the national education system, in terms of the management, the government still channels assistance to these schools (Umar, Saedin, Muslim, \& Hussin, 2018).

Although Malays have some privileges as dictated in the constitution, they have not obtained this from the asset confiscation of the non-Malays, but in turn, from the additional fund from the entire economy. The special rights of the Malays also do not affect the positions of the economy, politics and education as well as the politics of the non-Malays, but in the sectors of economy and education, they are better than Malays. The special rights of the Malays are also something that have existed before Independence and reinstated when the constitution is formulated. It is also an agreement achieved through ethnic negotiations. Although Malays are protected and granted special rights in the field of economy, the Malay conditions do not change that much. Although currently we have many Malay entrepreneurs running various business empires and Malay billionaires have even emerged, the number is still scarce. The success of few Malays in business cannot be seen as representing the success of the Malays in the field of economy. Permit reservation and business tender to certain Malays only widen the gap between the rich and the poor.

Referring to the Malaysian setting, Malaysia is a pluralistic country. This pluralistic nature will definitely create differences between ethnic groups in terms of their culture and religion. However, everyone is free to have their own faith and develop their own culture (Muslim, Musa, \& Buang, 2011). Non-Muslims are allowed to erect their own houses of worship where there are many religious followers. In politics, the selection of leaders is determined by the election which gives acknowledgement of justice to the people. In terms of the economy, the introduction of the national development policies such as New Economic Policy and National Development Policy, the Five-Year Development Plan, National Education Policy, National Cultural Policy also National Welfare Policy have taken into account the views of the people despite the fact that Malays have their own 
privileges as dictated in the Federal Constitution through Article 153 (Othman, 2007).

\section{Conclusion}

Islam has introduced the concept of ukhuwwah imaniyyah that can unite ethnic groups. Although the beliefs and faiths are different, Islam has the capability of harmonising the situations by emphasising on humanity and solidarity. Cruelty has to be combatted although the oppressor is of the same race and the oppressed is from a different ethnic group. Justivce should also be upheld for people from different ethnic groups. If Islam is really understood, a pluralistic society who lives in peace and harmony, can be materialised.

\section{References}

Abadi, M. S. (1990). 'Aun al-Ma'bud. Kitab Adab. Vol 14, Juz 14. Beirut: Dar al-Kutub Ilmiyyah.

Ahrah, M. A. (1987). Penyusunan Masyarakat Dalam Islam. Terj. Osman Khalid. Kuala Lumpur: Bahagian Hal Ehwal Islam, Prime Minister's Office.

Alhabshi, S. O. (2007). Keadilan sosial dalam negara Islam silam dan hubungannya dengan Malaysia kini. In Keadilan sosial dari perspektif Islam, ed. Khairul Azhar Idris. Kuala Lumpur: Institut Kefahaman Islam Malaysia.

Ali, M. M. (1996). The Muslim Community in Britain: A Historical Account. Petaling Jaya: Pelanduk Publication.

Bakar, O. (2008), Malaysian Islam in the twenty-first century: The promise of a democratic transformation? In J. L. Esposito, J. O. Voll, \& O. Bakar (Eds.), Asian Islam in the $21^{\text {st }}$ Century. New York: Oxford University Press.

Banna, H. (1403H). Kepentingan Keselamatan dan Keamanan Dalam Islam. Terj. Abdullah al-Qari. Kota Bharu: Pustaka ASA.

Bukhari, A. (1422H). al-Sahih, Jld 3. Beirut: Dar Touq al-Najah.

Daud A. (2009). Sunan, Jld 4. Beirut: Dar al-Risalah al-Alamiyyah.

Embong, Z., Musa, N. Y., \& Muslim, N. (2018). The Medina treaty from the ethnicity perspective. International Journal of Civil Engineering and Technology (IJCIET), 9(3), 1037-1048. Retrieved from http://www.iaeme.com/ijciet/issues.asp?JType=IJCIET\&VType=9\&IType=3

Hambal, A. I. (1422H). Masnad, Jld. 5. Beirut: al-Maktab al-Islami.

Hawwa, S. (2003). Ar-Rasul Shalallahu 'Alaihi Wa Sallam. Kuala Lumpur: Darulfikir.

Ibrahim, I. (2005). Perhubungan etnik menurut perspektif Islam. Working Paper for TITAS Curriculum and Ethnic Relations Seminar (National-level), 7-11 June 2005.

Mohamad, K. A. (2003). Kepelbagaian kaum dalam Islam: Hakikat dan tuntutan. Kertas kerja Seminar Hak dan Tanggungjawab Pelbagai Kaum dalam Sebuah Negara Islam. IKIM: Kuala Lumpur.

Muslim, A. (1422H). al-Sahih, Jld 4. Beirut: Dar Ihya`al-Turath al-Arabi.

Muslim, N., \& Umar, A. (2017). Malay Royal Institution According to the Federal Constitution within the Context of Ethnic Relations in Malaysia. Akademika, 87(1), 35-48. https://doi.org/10.17576/akad-2017-8701-03

Muslim, N., Musa, N. Y., \& Buang, A. H. (2011). Hubungan Etnik Di Malaysia Dari Perspektif Islam. Kajian Malaysia, 29(1), 1-28. Retrieved from http://web.usm.my/km/29(1)2011/KM\%20ART\%201(1-28).pdf

Muslim, N., Samian, A. L., \& Nizah, M. A. (2012). The Discrimination of Protection in the Federal Constitution from the Perspective of Ethnic Relations in Malaysia. Advances in Natural and Applied Sciences, 6(3), 447-451. Retrieved from http://www.aensiweb.com/old/anas_Jan_special2_2012.html

Qardhawi, Y. (1989). Kedudukan Non-Muslim Dalam Negara Islam. Terj. Mat Saad Abd. Rahman. Shah Alam: Hizbi Publication.

Qardhawi, Y. (1996). Membangun Ummah: Suatu Kenyataan Bukan Khayalan. Terj. Ahmad Nuryadi Asmawi. Batu Caves: Thinker's Library.

Ramadan, T. (2004). Western Muslims and the Future of Islam. New York: Oxford University Press. https://doi.org/10.1093/acprof:oso/9780195183566.001.0001

Umar, A., Saedin, M. S., Muslim, N., \& Hussin, S. (2018). History of Campaign for Rights in Education of 
Islamic and Chinese School Groups. International Journal of Civil Engineering and Technology, 9(4), 1584-1592. Retrieved from http://www.iaeme.com/ijciet/issues.asp?JType=IJCIET\&VType=9\&IType=4

Wan Abdullah, W. S., \& Syed Abdul Rahman, S. M. H. (2007). Beberapa syarat asas dialog agama: Pemerhatian ke atas beberapa ayat kunci alQuran. In W. S. W. Abdullah \& M. F. Hamat (Eds.), Konsep Asas Islam Dan Hubungan Antara Agama. Kuala Lumpur: Islamic Studies Academy.

\section{Copyrights}

Copyright for this article is retained by the author(s), with first publication rights granted to the journal.

This is an open-access article distributed under the terms and conditions of the Creative Commons Attribution license (http://creativecommons.org/licenses/by/4.0/). 